\title{
Správa společnosti a konkurenceschopnost: Existuje vazba?
}

\author{
Miroslav Hučka
}

\section{1. Úvod}

Správa společností, tj. systém, jakým jsou vlastnicky ovládány a kontrolovány společnosti, se v posledních letech dostala na celém světě do popředí zájmu. Důvodem pro to je na jedné straně všeobecný požadavek, aby se organizace mající velkou moc, musely za svou činnost ve větší míře zodpovídat, na druhé straně je to vznik globálních trhů. Vliv veřejně vlastněných společností stále stoupá a mají stále větší mezinárodní dosah.

Na celém světě se zvyšuje tlak na organizace různého druhu, vlády, veřejné orgány a obchodní společnosti, aby více zprůhlednily své aktivity a více naslouchaly těm, kterým slouží. Tento tlak doprovázejí požadavky na vyšší normy odpovědnosti, chování a výkonu.

Vysoká úroveň správy společností se celosvětově stává stále významnější otázkou dalšího rozvoje pro společnosti, které se snaží přilákat investice a získat kapitál. Na druhé straně účinná správa společnosti pomáhá vytvářet potenciál pro konkurenční výhodu, což je nezbytná podmínka pro její konkurenceschopnost na kolbišti trhu.

\section{Konkurenceschopnost a konkurenční výhoda}

Konkurenceschopnost podniku je široké teoretické i praktické téma, prostupující každodenním životem podniku. Vyrůstá z konkurenčních výhod, které si podnik vytvořil a udržuje. Základem pro získání konkurenční výhody jsou silné stránky podniku. Zdrojem konkurenční výhody jsou originální a hodnotné zdroje a charakteristické, unikátní schopnosti, které jsou jak udržitelné, tak uchopitelné. Takové způsobilosti nejsou opakovatelné u konkurentů, vyzvedávají jedinečné charakteristiky podniku a mohou být využity ve prospěch podniku.

Podle Portera (1997) vyrůstá konkurenční výhoda v podstatě z hodnoty, kterou je firma schopna vytvořit pro své zákazníky. Konkurenční výhoda je reálná schopnost, skutečnost, která se projeví nejen ve schopnosti výrobek navrhnout, vyvinout, ale i vyrobit a prodat za výhodnější ceny a ve větším množství než konkurenti (Slávik, 1999). Konkurenční výhoda znamená získat předstih, protože je na trh uváděn výrobek nebo služba, které konkurenti nedokáži vůbec poskytnout anebo nedokáží poskytnout s rovnocennými parametry.

Podle Jiráska (2001) může být konkurenční výhodou firmy téměř všechno. Pramení z mnoha jednotlivých aktivit, které firma provádí ve vývoji, výrobě, marketingu, distribuci a propagaci svého výrobku. Je mnohotvárná a její hodnota roste s počtem aspektů. Důležité

1 Prof. Ing. Miroslav Hučka, CSc., Vysoká škola báňská-Technická univerzita Ostrava, Ekonomická fakulta, Katedra podnikohospodářská. 
je, v jaké míře firmu diferencuje od konkurence, nakolik je atraktivní a přivolává zájem solventních zákazníků. Firma se může vyznačovat mnoha mimořádnými schopnostmi, ale pokud nejsou uplatněny v tržní rivalitě, leží mimo okruh konkurenčních výhod.

V diskusích o strategických otázkách podniků v Evropě jsou vyslovovány různé názory o zdrojích konkurenční výhody (Kay, 1994).

Ke zdrojům konkurenční výhody bývá zařazována velikost podniku a vizí pro budoucí strategie je rostoucí koncentrace na malý počet korporací ve většině odvětví průmyslu. $\mathrm{V}$ tomto kontextu je však zaměněn indikátor úspěchu s úspěšnými př́ípady. Existují samozřejmě podniky, které jsou jak velké, tak úspěšné. Avšak příčinnost se odvíjí od jejich úspěchu $\mathrm{k}$ velikosti, a nikoliv naopak. Bylo by chybné přijmout myšlenku, že kopírováním velikosti podniku by bylo možno opakovat jejich úspěch na trhu. Velikost podniku tedy nemůže být udržitelným zdrojem konkurenční výhody, nebot' velikost je něco, co konkurent může napodobit.

Dalším faktorem, který je diskutován, je podíl na trhu jako konkurenční výhoda. Tento názor vychází z prokázaných poznatků, že vysoký podíl na trhu a vysoká ziskovost spolu těsně souvisí. Avšak stejně jako vztah mezi velkostí a úspěchem nelze zaměňovat projevení konkurenční výhody s příčinami. Podniky s konkurenčními výhodami mají pravděpodobně jak vysoký podíl na trhu, tak ziskovost, avšak z toho nevyplývá, že podnik bez konkurenční výhody zvýší svou ziskovost zvýšením podílu na trhu. Z téhož důvodu z toho nevyplývá, že podnik, který má konkurenční výhodu, zvýší svou ziskovost zvýšením podílu na trhu.

Výše uvedené korelace může však podpořit to, že budování podílu na trhu je pravděpodobně část vytváření konkurenční výhody a že podnik s menším podílem na trhu nebude pravděpodobně mít udržitelnou pozici. Avšak vždy je nutno vzít v úvahu relativitu tohoto problému. Jestliže např. úspěšný podnik BMW zaujímá pouze o málo více než $1 \%$ světového automobilového trhu, pak jeho procentní podíl na sektoru luxusních vozů je mnohem vyšší ve vztahu k potenciální konkurenci.

Mnoho strategických diskusí se soustřed'uje na atraktivnost různých trhů. Na první pohled je zřejmé, že rychle rostoucí trhy, jako je elektronika, softwarový průmysl či finanční služby, jsou atraktivnější než upadající trhy jako je ocel nebo tabák. Z hlediska konkurenční výhody je to ale problém, nebot' jestliže jsou tyto trhy atraktivní, pak jsou atraktivní pro kohokoliv, kdo na takové trhy může rychle vstoupit.

Podobně je tomu s pozicí na trhu. Analýzy ukazují, že vysoké výnosy podniku jsou spojeny s kvalitou pozice na trhu. To však nejsou výnosy z pozice na trhu jako takové. Jsou výsledkem zřetelně výjimečné schopnosti podniku, která umožňuje, že právě tento podnik, a nikoliv jiné podniky, dosahuje takovou vysoce kvalitní pozici. Tatáź pozice nemusí produkovat stejné výnosy pro jiné podniky. Každý podnik by si měl vybrat takovou pozici, která odráží zcela rozdílně zdroje konkurenční výhody. Pozice na trhu tedy neposkytuje udržitelnou konkurenční výhodu. Většina získaných pozic na trhu může být napodobena. Na druhé straně jsou některé pozice na trhu obtížně napodobitelné (např. Microsoft), avšak to jen ukazuje, že opravdová konkurenční výhoda spočívá v kvalitě produktu a jejím rozpoznání ze strany zákazníka, a nikoliv v pozici na trhu jako takové. 


\section{Může být dobrá správa společnosti konkurenční výhodou?}

Jestliže jsme v předcházející části odmítli některé faktory udržitelné konkurenční výhody, pokusíme se na některé zdroje konkurenční výhody a cesty $\mathrm{k}$ jejímu získání odpovědět následujícími úvahami.

Vytváření konkurenční výhody vyžaduje formulovat vhodnou konkurenční strategii. G. Hamel (1998) přišel s myšlenkou soutěžení pro budoucnost jako tvorbou průkopnických strategií orientovaných na redefinování a získání vůdčí pozice na trzích zítřka. Formuloval tyto otázky:

Jak vlivná je moje firma při určení nových pravidel konkurence v rámci celého odvětví?

Jaká je její úloha při definování nových cest podnikání, budování nových kapacit a stanovení nových standardů uspokojení zákazníka?

Je spíše realizátorem pravidel než určovatelem pravidel v rámci svého odvětví?

Je spíše odhodlána k výzvám na změnu statu quo odvětví než k jeho obraně?

To jsou otázky, které vyvolává nejen firma, nýbrž také okolí, ve kterém operuje - její zákazníci, dodavatelé, věřitelé, konkurenti a především její zaměstnanci. Obrátit takovou výzvu na konkurenční př́ležitost vyžaduje angažovanost všech těchto zájmových skupin, které by měly být zahrnuty do procesu vytvárení budoucnosti a formování odpovídajících průkopnických strategií.

Soutěžení pro budoucnost $\mathrm{v}$ podmínkách intenzifikace konkurence znamená, že iniciativa pro vytvoření úspěchu na trhu je v rukou jednotlivých firem. Jednou z forem, jak může být tato iniciativa realizována, je úsilí o užší vztah se zájmovými skupinami v podnikání firmy s cílem hlouběji pochopit, jak nejlépe naplnit reálné a potenciální potřeby trhu a jak vtáhnout do tohoto procesu zájmové skupiny. Tento proces ,inkluze“ je systémem sdílené hodnoty, zahrnujícím dodavatele, zákazníky, zaměstnance, místní komunity, $\mathrm{v}$ nichž firma operuje, a její akcionáře a formuluje př́ístup firmy $\mathrm{k}$ nim:

- jasně definuje účel firmy a její hodnoty a sděluje je konzistentním způsobem všem důležitým činitelům pro úspěch firmy;

- aktivně udržuje reciproční vztahy s klíčovými zájmovými skupinami na bázi partnerství;

- vztahy se zájmovými skupinami používá $\mathrm{k}$ rozvoji svého vlastního modelu úspěchu a ke zlepšení výnosů pro akcionáŕe;

- očekává od svých vztahů silné potvrzení svého poslání.

Tento př́stup se transformuje do podnikatelské strategie, která je širší než strategie soustředěná na hodnotu pro akcionáře. Zisk se stává prostředkem pro všestranný rozvoj a nepřetržitý růst firmy. Proces inkluze umožňuje firmě zvyšovat uvědomění o jejích výrobcích a službách a budovat širši platformu zájmových skupin, které na základě toho mohou udržovat a rozšiřovat své aktivity. Strategie inkluze ve velké míře závisí na stálé obnově důvěry zájmových skupin. 
Budování širší platformy zájmových skupin představuje budování množiny smluvních vztahů s nimi. Odlišná identita každého podniku je postavena na odlišném charakteru množiny těchto vztahů. Volba množiny smluv definováním podnikatelských aktivit a umístění podniku vzhledem k jeho skutečným a potenciálním konkurentům je ústředním bodem podnikatelské strategie. Kvalita a odlišitelnost množiny smluv jsou dosahovány především vyvinutím takové množiny smluvních vztahů, které ostatní podniky nedokáží zajistit. 1994):

Existuje několik cest, jak vytvořit odlišitelnou množinu smluvních vztahů (Kay,

- provedení nového uspořádání smluv $\mathrm{v}$ souvislosti $\mathrm{s}$ výrobkovými nebo technologickými inovacemi;

- uzavírání smluv za podmínek, které vyplývají z pověsti (renomé, dobrého jména) podniku;

- uzavírání takových smluv, které ostatní podniky nejsou schopny uzavřít, $\mathrm{a}$ to $\mathrm{z}$ titulu výjimečného př́stupu $\mathrm{k}$ vzácným zdrojům anebo $\mathrm{v}$ důsledku zákonných omezení, přirozeného monopolu nebo strategické pozice podniku.

Odlišitelnost množiny smluv vyústí do komplexu smluv chápaného jako celek, do uspořádání podniku. Zatímco kterákoli jediná smlouva anebo část smluv mohou být reprodukovány, komplex smluv imitaci vzdoruje. Pod uspořádáním podniku chápeme vnitřní strukturu podniku, prostřednictvím níž podnik dosahuje růst odborné způsobilosti (know how) a etiky spolupráce.

Odborná způsobilost (know how), charakteristická pro podnik, je více než součet způsobilostí těch, kteří pracují v podniku, a není dostupná jiným podnikům. Odborná způsobilost je konkurenční výhodou na trhu pro danou kategorii produktu a často může být aplikována jen pro velmi úzce definovaný trh.

Etika spolupráce může být odlišnou schopností a základním zdrojem konkurenční výhody na trzích, které vyžadují pružnou odezvu nebo rychlý tok informací. Spočívá ve vzájemně výhodných smluvních vztazích a pravdivém sdílení informací při sledování sdílených cílů smluvních partnerů.

V souvislosti s uspořádáním podniku je zapotřebí se věnovat dvěma problémům. Prvním z nich je schopnost imitace. Jestliže množina smluvních vztahů, prostřednictvím níž je dosahováno konkurenční výhody, může být formalizována a prováděna rutinně, pak může být napodobena a v takovém př́ipadě je nutno upustit od myšlenky, že by mohla být zdrojem konkurenční výhody. V minulosti bylo učiněno mnoho pokusů opakovat uspořádání úspěšných podniků. Tyto pokusy vycházely bud' z veřejně dostupných publikací o úspěšných podnicích, nebo $\mathrm{z}$ přechodu řady zaměstnanců úspěšných podniků $\mathrm{k}$ podnikům konkurenčním. Studiem publikací ani získáním zaměstnancủ však nedošlo k transferu odborné způsobilosti a zavedení etiky spolupráce, ani $\mathrm{k}$ dostatečnému pochopení struktury smluv a smluvních vztahů, které vedly k dosažení konkurenční výhody.

Druhým problémem je podstata vztahů zahrnutých v tvorbě odborné způsobilosti a zavedení etiky spolupráce. V uspořádání podniků, které úspěšně dosahují konkurenční výhodu, lze pozorovat očekávání dlouhodobých vztahů uvnitř i vně podniku a vysoký stupeň neformálních vztahů na bázi rozsáhlé množiny nepsaných pravidel a očekávání chování partnerů v souladu s formálními povinnostmi klasických smluv. 
Klíčovou otázkou při vývoji uspořádání podniku je potřeba vytvořit důvěru a potlačit oportunismus v síti smluvních vztahů. To je usnadněno, jestliže obchodní vztahy jsou podpořeny odpovídající sítí sociálních vztahů, nebot' všichni inklinují $\mathrm{k}$ tomu, že více důvěřují lidem, které znají. Některé sociální prostředí je více př́znivé pro rozvoj konkurenční výhody než jiné.

Výše uvedené úvahy vyvolávají otázku, do jaké míry je možno předpokládat kauzální závislost mezi úrovní správy a úspěšností podniku v dosahování strategických cílů, zejména ve vytvoření a udržení konkurenční výhody. Vztah mezi úrovní správy a úspěšností podniku byl a dosud je předmětem diskusí (viz např. Kakabatse, Kakabatse, Kouzmin, 2001). Řada empirických analýz však hypotézu o pozitivní korelaci mezi úrovní správy a úspěšností podniku, vyjádřené růstem hodnoty pro akcionáře, potvrdila (Malý, Theodor, Peklo, 2002). V tomtéž prameni se uvádí prístup profesora Atkinsona a jeho týmu na universitě Waterloo v Kanadě, kteří vyvinuli metodu kvantitativního strategického měření výkonnosti podniku s využitím koncepce zájmových skupin. Podle jejich koncepce jsou vztahy s vybranými zájmovými skupinami klíčové pro plnění strategických cílů podniku. Jednotlivé zájmové skupiny mají svoje primární cíle a zájmy, které pro podnik představují sekundární cíle. Dosahování a plnění těchto cílů jednotlivými zájmovými skupinami však zprostředkovaně napomáhá podniku k plnění jeho primárního cíle.

\section{Měření úrovně správy společnosti}

V osmdesátých letech minulého století se rozvinula diskuse o správě společností a soustředila se na otázky efektivnosti a odpovědnosti správních orgánů. Kritika se zaměřovala na slabý vliv akcionářů, nedostatek podnikavosti, vůdcovství a řízení ze strany správních orgánů.

Řada velkých společností ve Spojených státech začala přezkoumávat svůj postoj ke správě společností a vypracovala vlastní směrnice k významným otázkám správy společností, které byly dobrovolně přijaty jako interní návody $\mathrm{k}$ jednání. Rovněž v řadě dalších zemí mimo USA došlo ke zveřejnění zpráv o správě společností, doprovázených doporučenými směrnicemi nebo kodexy nejlepší praxe. Vliv těchto kodexů se rozš́iřil daleko za hranice jejich původu.

Návrhy týkající se způsobu správy společností, které jsou předkládány v různých zemích světa, mají společné dva cíle. Oba jsou zaměřeny na lepší zodpovídání se ze strany správních orgánů a na jejich efektivní činnost.

Prvním cílem je posílení vlivu akcionářů, což ve skutečností znamená přiblížení praxe správy společností k teoretickému modelu. Různost zájmů manažerů a akcionárůu, která se projevuje, vyvolává nutnost hledání rovnováhy mezi jejich pravomocemi. Převládá názor, že v minulosti se miska vah přikláněla spíše na stranu manažerů.

Druhým cílem je posílení výkonu vlastních řídících funkcí ve společnosti ze strany správních orgánů. Mají-li být správní orgány efektivní a zodpovídat se za svá rozhodnutí, musí být jejich řídící kompetence jasné a silné.

Toto zaměření na úlohu správních orgánů je důsledkem rychle probíhajících změn ve světě společností. Na rozvíjejících se, ale i stále se měnících, zavedených trzích se volá po vyšších normách v podnikání a po tom, aby společnosti přihližžely k širším zájmům. Úkoly 
správních orgánů jsou tudíž náročnější a velmi důležitý je způsob, jakým reagují na výše uvedené požadavky.

Návrhy na zlepšení způsobu řizení společností mají na celém světě řadu více či méně společných prvkủ, které se dají charakterizovat takto:

- zveřejňování informací finančního charakteru, tj. požadavek, aby správní orgány nezatajovaly aktivity společností, které rídí. Otevřenost společnosti je považována za podmínku pro budování důvěry veřejnosti.

- vzájemná kontrola a vyváženost ve struktuře ř́zení, zvláště na úrovni správních orgánů. Účelem je zabránit nevhodnému soustřed’ování moci a zajistit konstruktivní diskusi vedoucí k dobře podloženým rozhodnutím správních orgánů.

- vytváření mechanismů pro řešení divergence zájmů akcionářů a těch, kteří společnost $\mathrm{v}$ jejich zastoupení ř́dí. Jde $\mathrm{v}$ podstatě o zastupitelský problém a jeho řešení.

- uznávání práv zájmových skupin a podpora jejich aktivní spolupráce.

Doporučení kodexů společností zatím měla jen malý vliv na harmonizaci mezi systémy správních orgánů $\mathrm{v}$ různých zemích. Zásadní rozdíly v př́istupu $\mathrm{k}$ otázce správy společností v Evropě a ještě více v mezinárodním měřítku to neumožňují.

K překážkám harmonizace systémů správních orgánů patří rovněž otázka zastoupení zaměstnanců $\mathrm{v}$ nich. Zatímco pro Německo je nepřijatelné, aby došlo $\mathrm{k}$ oslabení principu spolurozhodování a zastoupení zaměstnanců ve správních orgánech, Velká Británie naopak nehodlá prristoupit na strukturu, která by takové zastoupení zahrnovala.

Kodexy je možno považovat za podpůrné, dobrovolné, samoregulační nástroje společností. Významná je skutečnost, vyplývající z četných průzkumů, že společnosti, které jsou dlouhodobě úspěšné, zpravidla dodržují doporučení kodexu, uvedená výše. To nepřekvapuje, nebot' doporučení kodexů jsou úzce spojena s nejlepší praxí. Jisté je, že struktury řízení společností, které nevyhovují príijatým normám, čelí zvýšenému riziku podvodů, neúspěchu společnosti nebo obojího. V posledním desetiletí začíná být soulad s určitým kodexem dobré praxe podmínkou veřejné obchodovatelnosti akcií společnosti na některých akciových burzách.

Zatímco kodexy představují kvalitativní př́stupy měření úrovně správy společností se silnými subjektivními prvky, byly vyvinuty metody, které vycházejí z více či méně objektivních kvantitativních ukazatelů pro měření úrovně správy společností. Existuje několik kvantitativních přístupů, které nabízejí různé konzultantské a poradenské firmy.

Pro ilustraci stručně uvedeme metodologii firmy Standard and Poor's, umožňující porovnávat standardy správy společností.

V roce 2001 byla zahájena nová služba pro investory a podniky s názvem Hodnocení správy společnosti (Corporate Governance Scores - CGS). CGS odráží zhodnocení praktik a politik správy dané společnosti firmou Standard and Poor's. Toto zhodnocení může být provedeno veřejně nebo důvěrně a zahrnuje analýzu veřejných i neveřejných informací a provedení pracovních diskusí s řediteli a špičkovými manažery dané společnosti. Nakonec je provedeno ocenění pomocí stupnice od CGS - 10 (nejvyšší ocenění) do CGS - 1 (nejnižší ocenění). 
Metodika hodnocení standardů správy společnosti Standard and Poor's zahrnuje čtyři hlavní skupiny indikátorů.

První skupina - vlastnická struktura aktiv - zahrnuje analýzu transparentnosti vlastnické struktury a vlivu hlavních akcionářů nebo držitelů balíku akcií.

Ve druhé skupině - práva akcionár̆ů a vztahy se zájmovými skupinami - jsou hodnoceny kvalita interakce společnosti s jejími finančními zájmovými skupinami ${ }^{2}$ (např. procedury valné hromady akcionářù) a práva udělená finančním zájmovým skupinám. Je rovněž brán $\mathrm{v}$ úvahu dopad obranných opatření proti převzetí, která by mohla zmařit jinak legitimní pokus o převzetí.

Ve třetí skupině - finanční transparentnost a odhalování informací - jsou měřeny kvalita, dostupnost a včasnost finančních a operativních informací pro finanční zájmové skupiny. Analýza zahrnuje zhodnocení veřejných databází, ročních zpráv a internetových stránek.

Nakonec se analýza zabývá strukturou a procesy správních orgánů a hodnotí strukturu a účinnost rady ředitelů, roli a nezávislost neexekutivních ředitelů, ř́zení rizika, stanovenou strategii a problémy odměňování a nominace.

Je důležité poznamenat, že různé modely správy společnosti ve světě odrážejí charakter místních právních a regulačních systémů, jakož i rozdílné přistupy k ekonomickému řízení. Anglosaský systém správy se primárně soustřed’uje na akcionáře, zatímco např́klad německý systém je spíše chápán jako dosahování větší rovnováhy zájmů mezi akcionáři a dalšími zájmovými skupinami (včetně věřitelů, zaměstnancủ, zákazníků, komunity apod.). CGS uznává práva jednotlivých zájmových skupin vedle práv akcionářu a tudíž může být aplikován $\mathrm{v}$ různých zemích s rozdílnými př́stupy ke správě společností. Je však nutno zdůraznit, že CGS je určen především pro finanční zájmové skupiny, zejména pro akcionáře.

Ačkoliv CGS odráží ocenění praktik a politik správy dané společnosti a soustřed’uje se na její vnitřní strukturu a procesy správy, důležitým prvkem celkové analýzy je rovněž zahrnutí právního, regulačního a tržního prostředí dané země. Např́ílad dvě společnosti se shodným CGS, avšak fungující v zemích s odlišnými právními, regulačními a tržními standardy, představují různé rizikové profily. V př́padě zhoršení standardů správy v některé společnosti budou mít investoři a zájmové skupiny lepší ochranu v zemi se silnými a lépe vynutitelnými zákony a regulací.

\section{Výsledky empirických průzkumů v angloamerickém prostředí}

Pokud podnik disponuje konkurenční výhodou a je na trhu konkurenceschopný, projevuje se to u něj dosahováním příznivých hospodářských výsledků a odpovídajících pozitivních hodnot indikátorů výkonnosti. V další části na základě výsledků empirických průzkumů $\mathrm{v}$ angloamerickém prostředí diskutujeme oprávněnost všeobecně uznávané představy, že správu společnosti lze chápat jako významný činitel pro výkonnost

2 Pod pojmem finanční zájmové skupiny jsou zahrnuti jak akcionáři, tak věřitelé společnosti. To odráži předpoklad, že kvalita správy společnosti postihuje jak její schopnost respektovat smluvní finanční závazky k věřitelům, tak maximalizovat hodnotu jmění společnosti a rozdělení výnosů pro akcionáře. 
společnosti, tedy předpokladu kauzální souvislosti mezi úrovní správy společnosti a její úspěšností v plnění vytýčených cílů, zejména v růstu hodnoty pro akcionáře.

Rozsáhlé průzkumy britských a amerických společností (Kakabatse, 2001) provedené koncem devadesátých let minulého století ukazují, že vztah mezi úrovní správy společnosti a její finanční výkonností není jednoznačný a systematický. Na základě těchto výsledků se z různých stran, zejména od investorů, projevila určitá skepse, spočívající v pochybnostech o existenci vazby mezi dobrou správou společnosti a indikátory její výkonnosti, jako je např́klad cena akcií.

Ačkoliv existuje rostoucí množství literatury týkající se vztahu mezi správou společnosti a její výkonností, existuje stejně tak různost výsledků. Ta může být částečně vysvětlena rozdíly $\mathrm{v}$ aplikovaných teoretických východiscích, $\mathrm{v}$ uplatněných vědeckých metodologiích, ve způsobech měření výkonnosti a v konfliktních hlediscích na otázku angažovanosti správních orgánů v rozhodování.

Mnoho studií zkoumajících vztah mezi proměnnými ze čtyř komplexů vlastností správního orgánu a výkonností společnosti ukázalo negativní vztah anebo žádný statisticky významný vztah (Dalton aj., 1998). Jiné analýzy dat za období 40 let ze 159 studií provedené Daltonem a Dailym (1999) došly k závěru, že neexistuje jasný důkaz o podstatném vztahu mezi složením správního orgánu a finanční výkonností, a to bez ohledu na volbu ukazatelů výkonnosti, velikost společnosti nebo způsob, jakým je měřena struktura správního orgánu. Tudíž spoléhání se na jakoukoli dimenzi rolí a vlastností správního orgánu nezajistí vysokou úroveň finanční výkonnosti společnosti.

Dosud dosažené výsledky výzkumu správy společnosti byly ovlivněny řadou omezení. Především poznatky jsou roztřištěné v důsledku různých pohledů - sociologického, ekonomického, organizačního a strategického - což vedlo k různé terminologii a interpretaci (Kakabatse, 2001). Navíc většina empirických studií není dostatečně podložena teorií, a ty, které jsou, se soustřed’ují na strukturální dimenze správního orgánu a málo se věnují otázkám chování správního orgánu. Ve většině studií byl též značně ignorován vliv kontextových proměnných (Kakabatse, 2001).

Potřeba začlenit kontextové proměnné do hodnocení správy společnosti a její výkonnosti byla identifikována v USA institucionálními investory. Některé př́ípadové studie ukazují, že kontextové proměnné, jako jsou ekonomická, sociální a politická struktura a zákonný finanční systém, mají dopad na správu a výkonnost společnosti (Kakabatse, 2001). Vyplývá z nich, že institucionální investoři jsou ochotni platit prémii za dobrou správu společnosti ve výši 16-18 \% v USA a Velké Británii, $22 \%$ v Itálii apod. (Investors Relations Business, 2000). Ukazuje se rovněž, že významnou doplňující kontextovou proměnnou je aktivita akcionár̆ù.

V poslední době bylo předloženo rostoucí množství nových důkazů, svědčících o tom, že vazby mezi úrovní správy společnosti a indikátory její výkonnosti existují (Bradley, 2004). V průzkumu dokončeném v roce 2002 získala konzultační firma Mc Kinsey \& Company názory institucionálních investorů na rozvíjejících se a rozvinutých trzích. Studie zjistila, že investoři při provádění investičních rozhodnutí kladou správu společnosti na roveň finančním indikátorům. Navíc se ukázalo, že zdrcující většina investorů je připravena zaplatit prémii za ty společnosti, které vykazují vysoký standard správy. Podobně ukázal průzkum téměř 500 společností z rozvíjejících se ekonomik (CLSA, 2002) silnou korelaci mezi správou společnosti a ukazateli finanční výkonnosti a došel k závěru, že téměř bez výjimky ceny akcií společností se špičkovou úrovní správy mají v posledních letech stoupající trend. 
Pokud jde o vazby mezi správou společnosti a indikátory finanční výkonnosti na rozvinutých kapitálových trzích, např. v USA, studie amerických firem hodnocených v letech 1990 až 1999 zjistila zřetelný vztah mezi správou společnosti a výnosy akcií (Gompers aj., 2001) a předložila důkaz o tom, že investiční strategie, spočívající v zakoupení firem s nejsilnějšími právy akcionářů a prodeji firem $\mathrm{s}$ nejslabšími právy akcionářů, dosáhla mimořádných výnosů ve výši $8,5 \%$ za rok.

Navzdory rostoucímu objemu uvedených důkazů existuje ještě mnoho společností, které nejsou přesvědčeny o sledované vazbě mezi správou společnosti a indikátory výkonnosti, a praktické přijetí principů dobré správy je přinejmenším různorodé. $\mathrm{K}$ této situaci přispívá rovněž skutečnost, že zatím nejsou definována vztažná měřítka pro poměřování standardů správy společnosti.

Vztah mezi správou společnosti a indikátory její finanční výkonnosti jednoznačně prokazuje, že úroveň správy společností nelze podceňovat. V minulých letech, kdy došlo k rozsáhlým skandálům $\mathrm{v}$ důsledku selhání správy společností, se tato problematika spolu s etickými standardy dostala do popředí zájmů veřejnosti a akcionářů. Jedním z vyplynuvších požadavků je dodržovat všeobecně deklarované principy přijatých etických kodexů dobré správy společností. Společnosti, které se řídí tímto kodexem, zveřejňují informace o svém fungování v roční výroční zprávě. Tudíž akcionáři a zájmové skupiny mohou posoudit, zdali společnost řádně plní své povinnosti a odpovědnost vưči nim. Společnosti, které $\mathrm{v}$ tomto směru selhávají, mohou ztratit svou legitimnost a nárok na existenci prostřednictvím soudních řizení anebo bojkotu ze strany zájmových skupin.

\section{Hypotéza pro české prostředí}

České společnosti prošly v minulém desetiletí nejrychlejším a nejkomplexnějším privatizačním programem ze všech transformujících se zemí střední a východní Evropy. Privatizace sama o sobě nepostačuje ke zlepšení výkonnosti ekonomiky. Výkonnost ekonomiky bude z velké části závislá na účinnosti modelu správy společností, který se začal vyvíjet od roku 1991, kdy byla nastartována velká privatizace. Jak ukazují zkušenosti vyspělých tržních ekonomik, vývoj plně rozvinutého a účinného systému správy společností je otázkou desetiletí.

Český model správy společností je založen na bankách, které sehrávají významnou roli ve výkonu vlastnické kontroly společností prostřednictvím svých fondů a půjček. Rozsáhlá angažovanost bank ve vlastnických podílech na majetku podnikového sektoru jim umožňuje realizovat úspory z rozsahu ve výkonu správy společností.

Kupónová privatizace připravila cestu k trhu pro kontrolu společností, který významně přispěl ke koncentraci vlastnických podílů. Otevřenost vlastnických struktur zvýšila pro každou společnost šanci získat schopného vlastníka. To zmírnilo značný nedostatek konkurence ve správě mnoha společností. Avšak kladné účinky otevřených vlastnických struktur byly zeslabeny nedokonalostí právního rámce a slabým prosazováním a vynucováním zákona. Trh pro kontrolu společností (představovaný burzou cenných papírů a RM-systémem) po počátečním vstupu několika set emisí z první a druhé vlny kupónové privatizace se $\mathrm{v}$ průběhu několika let ukázal jako informačně málo účinný a v důsledku nedostatku kapitálu nelikvidní. Posléze z něj bylo vyřazeno velké množství nelikvidních emisí. V současné době operuje na burze cenných papírů několik společností a na RM-systému několik desítek společností. V důsledku těchto skutečností nelze očekávat, že český model správy 
společností přijme $\mathrm{v}$ dohledné době finanční systém založený na trhu a zůstane proto i nadále bankovně orientován.

Co můžeme v této situaci říci ke vztahu mezi správou a výkonností společnosti v českém prostředí? Jelikož nemáme $\mathrm{k}$ dispozici žádné závěry z empirických výzkumů, můžeme vyslovit pouze hypotetické úvahy.

Tvrdíme, že pro výkonnost společnosti je důležité celkové klima a tradice vynucování smluv a vlády zákona (Cohen, 2000). Kvalitní právní ochrana investorů a síla vlády zákona vysvětluje některé rozdíly v kapitálové struktuře společností. V souladu s tím přijmeme hypotézu, že lepší právní ochrana investorů a silnější vláda zákona přispějí ke zvýšení úrovně správy společností, což bude nakonec spojeno s lepší výkonností těchto společností.

Systém správy společnosti v českém prostředí se teprve usazuje a výkonnost společností je př́liš mnohotvárná, než aby nám dovolily jednoznačná doporučení pro budoucí změny a reformy. Přesto silnější právní ochrana věřitelů a akcionářù a silná oddanost vládě zákona se zdají být neztrátovými návrhy, které by měly být přijaty pro zlepšení správy společností, jakož i celkového fungování české ekonomiky.

\section{Závěr}

Správa společností se opírá o vnitřní mechanismy, které zabezpečují vlastnickou kontrolu. Dobrý režim správy společností pomáhá zajistit, aby společnosti využívaly svůj kapitál účinně. $\mathrm{V}$ několika minulých letech se správa společností a etika staly důležitým problémem pro dobré jméno společnosti jako odezva na skandály a selhání správy mnoha světových společností. Rovněž prostředí v České republice po kupónové privatizaci nepodporovalo dobré zásady správy společností a umožnilo nápaditým vlastníkům a manažerům podniků odčerpat z podniků podstatnou část jejich hodnoty. Rada podniků se však dostala do hospodářských problémů také v důsledku nezáměrného selhání na úrovni vrcholového vedení, mimo jiné též proto, že neexistoval účinný rámec správy společností.

Trvalé zlepšování správy společností se stalo úkolem doby. Vysoká úroveň správy společností se celosvětově stává pro společnosti, které se snaží přilákat investice a získat kapitál, stále významnější otázkou jejich dalšího rozvoje. Na druhé straně účinná správa společnosti pomáhá vytvářet potenciál pro konkurenční výhodu, což je nezbytná podmínka pro její konkurenceschopnost na kolbišti trhu. 


\section{Literatura}

BRADLEY, N.: Corporate governance scoring and the link between corporate governance and performance indicators: in search of the Holy Grail. Corporate Governance, 2004, č.1, s. 8-10.

CLSA Emerging Markets: Make me holy...but not yet. February 2002.

COHEN, S. S. - BOYD, D. (eds.): Corporate governance and globalization: long range planning issues. Edward Elgar Publishing Ltd. Cheltenham 2000. Part 2. Corporate Governance and Corporate Performance.

DALTON, D. R. - DAILY, C. M. - ELLSTRAND, A. E., JOHNSON, J. L.: Meta-analytic review of board composition, leadership structure and financial performance. Strategic Management Journal, 1998, No. 2.

DALTON, D. R. - DAILY,C. M.: What's wrong with having friends on the board? Across the Board, 1999, No. 3.

DAVIES, A. H. T.: A Strategic Approach to Corporate Governance. Aldershot: Gower Publishing Limited, 1999.

DAVIS, G. F. - THOMPSON, T. A.: A social movement perspective on corporate control. Administrative Science Quarterly, 1994, č. 1.

DEMIRAG,I.S. (ed.): Corporate Governance. Accountability and Pressures to perform. An International Study. Stamford: Jai Press Inc., 1998.

GOMPERS, P. - ISHII, J. - METRICK, A.: Corporate Governance and equity prices. July 2001.

HAMEL, G.: Zásadni obnova konkurenční základny. In: Nový obraz budoucnosti. Praha: Management Press, 1998.

HUČKA, M.: Vlastnická správa korporací. Sborník vědeckých prací Vysoké školy báňské-Technické univerzity Ostrava. Ostrava: VŠB-TU 2002.

Investors Relations Business (IRB): Good governance pays off: institutions will pay a premium for an independent board. Staff Reports, Institutional Shareholders Services Inc. 3. 3. 2000 .

JIRÁSEK, J. A.: Konkurenčnost. Vitězství a porážky na kolbišti trhu. Praha: Professional Publishing, 2001.

KAKABATSE, N. - KAKABATSE, A. K. - KOUZMIN, A.: Board governance and company performance: any correlations? Corporate Governance, 2001, No. 1.

KAY, J.: Corporate Strategy and Corporate Accountability. In: Capital Market and Corporate Governance. Oxford: Clarendon Press, 1994.

KOČENDA, E. - LÍZAL, L.: Český podnik v české transformaci 1990-2000. Praha: Academia, 2003. Kap. 9 Vlastnické struktury a výkonnost kupónově privatizovaných podniků. 
MAASSEN, G. F.: An International comparison of corporate governance models. Amsterdam: Spencer Stuart, 1999.

MALÝ, M. - THEODOR, M. - PEKLO, J.: Řizení a správa společností (Corporate Governance). Praha: VŠE, 2002.

Mc Kinsey \& Company: Global investor opinion. July 2002.

PORTER, M.: Konkurenční výhoda. Praha: Victoria Publishing, 1997.

SLÁVIK, Š.: Strategické riadenie podniku. Bratislava: Sprint, 1999.

ZAHRA, S. A. - PEARCE, J. A.: Board of directors and corporate financial performance: a review and integrative model. Journal of Management, 1989, No. 2. 


\title{
Správa společnosti a konkurenceschopnost: Existuje vazba?
}

\section{Miroslav Hučka}

\begin{abstract}
Abstrakt
Příspěvek se zabývá problematikou vztahu mezi úrovní správy společnosti a její konkurenceschopností. Diskutuje konkurenceschopnost podniku, která vyrůstá z konkurenčních výhod. Hledá odpověd' na některé zdroje konkurenční výhody a cesty k jejímu získání. Prezentuje kvalitativní i kvantitativní príistupy měření úrovně správy společností. Analyzuje výsledky empirických průzkumů v angloamerickém prostředí, pokud jde o vztah mezi indikátory finanční výkonnosti a správou společnosti, ukazuje na rostoucí množství nových důkazů existence pozitivní vazby. V závěru př́spěvku je vyslovena hypotéza pro české prostředí, že lepší právní ochrana a dodržování zákona přispějí ke zvýšení úrovně správy společností a jejich výkonnosti.
\end{abstract}

